\section{Compression after trauma}

\section{Rolf Jelnes}

Wound Clinic, Medical Center, Sygehus Sonderjylland, Sonderborg, Denmark

Traumatic ulcers are a large entity in wound care. In our clinic, data from the database ${ }^{1}$ show that the number of patients is comparable to venous leg ulcers, diabetic foot ulcers and pressure ulcers (Table 1). In spite of this, not very much is written about the entity in the literature.

The traumatic wounds are typically located on the anterior and lateral aspect of the lower limb. The causes are different from low energy trauma (as stumbling up the stairs or a trolley in the supermarket (Figures 1 and 2) to accidents with a sharp trauma.

After low energy trauma, the patients are able to continue their daily work until a lesion appears on the skin. When it increases in size the patient seeks the General Practitioner who typically prescribes an antibiotic treatment. If nothing else is done, apart from moist wound healing, the time to heal can be as long as more than 6 months with the well known consequences for the patient and the society in terms of personal and social costs.

Studies on deep tissue injury have shown that cell deformity, within minutes, causes cell damage leading to cell death. ${ }^{2}$ The subcutaneous tissue is the tissue with lowest blood perfusion, thus making it more susceptible to ischemia.

A possible mechanism for the development of the traumatic ulcer could be: i) subcutaneous adipose tissue cells die, due to the blunt trauma; ii) within the cell the osmotically active proteins are let loose themselves in the interstitium, drawing water to the area; iii) edema is created in the ageing skin the amount of collagen and elastin is reduced ${ }^{3}$ especially in women after menopause, leading to reduced forces to counteract the edema (intrinsic compression).

As an edema has developed, the rationale for compression, with either bandages or stockings with high stiffness, seems obvious. The impressive healing rate of $25 \%$ per week (Table 1) supports this view.
Table 1. Distribution of wounds according to underlying diagnosis.

\begin{tabular}{lcc} 
& $\begin{array}{c}\text { Number } \\
\text { of wounds }\end{array}$ & $\begin{array}{c}\text { Healing } \\
\text { rate per week }\end{array}$ \\
Traumatic ulcers & 558 & $25 \%$ \\
Pressure ulcers & 503 & - \\
\hline $\begin{array}{l}\text { Venous leg ulcers } \\
\text { Neuropathic foot }\end{array}$ & 450 & $18 \%$ \\
ulceres & 444 & - \\
\hline $\begin{array}{l}\text { Neuroischemic } \\
\text { foot ulcers }\end{array}$ & 283 & \\
\hline
\end{tabular}

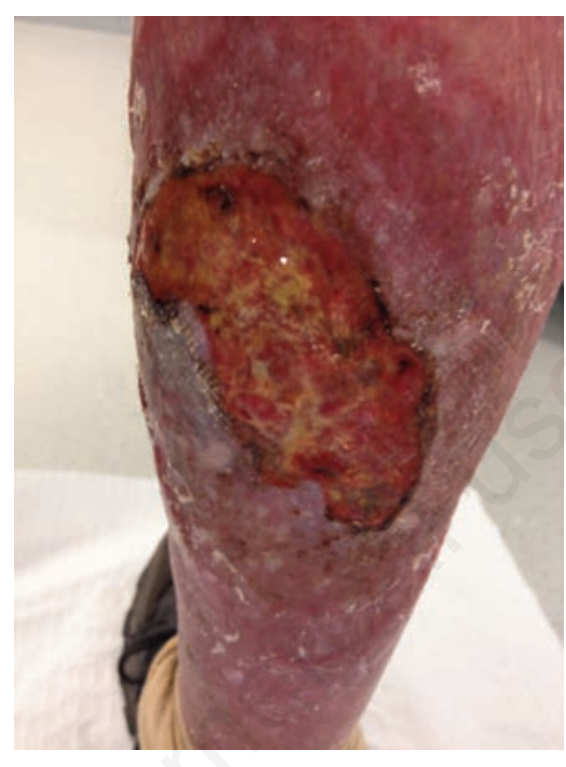

Figure 1. Large traumatic ulcer on the postero-lateral aspect of the calf.

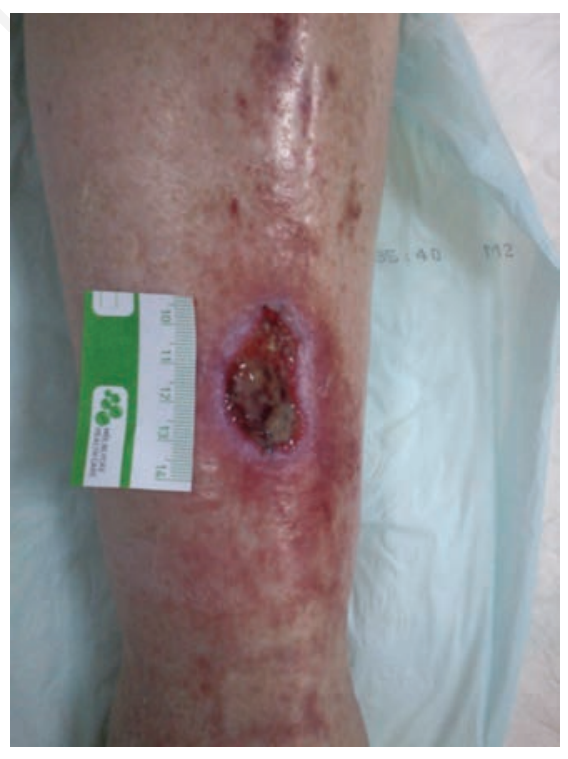

Figure 2. Traumatic ulcer on the anterior aspect of the calf.
Correspondence: Rolf Jelnes, Wound Clinic, Medical Center, Sygehus Sønderjylland, Sydvang 1, 6400 Sønderborg, Denmark.

E-mail: rolf.jelnes@stofanet.dk

This work is licensed under a Creative Commons Attribution 4.0 License (by-nc 4.0).

(C) Copyright R.Jelnes, 2016

Licensee PAGEPress, Italy

Veins and Lymphatics 2016; 5:5988

doi:10.4081/vl.2016.5988

\section{References}

1. Hafner J, Nobbe S, Partsch H, et al. Martorell hypertensive ischemic leg ulcer: a model of ischemic subcutaneous arteriolosclerosis. Arch Dermatol 2010;146:9618.

2. Senet P, Beneton N, Debure C, et al. Hypertensive leg ulcers: epidemiological characteristics and prognostic factors for healing in a prospective cohort. Ann Dermatol Venereol 2012;139:346-9.

3. Senet P, Vicaut E, Beneton N, et al. Topical treatment of hypertensive leg ulcers with platelet-derived growth factor-BB: a randomized controlled trial. Arch Dermatol 2011;147:926-30.

4. Vuerstaek JD, Reeder SW, Henquet CJ, Neumann HA. Arteriolosclerotic ulcer of Martorell. J Eur Acad Dermatol Venereol 2010;24:867-74. 